
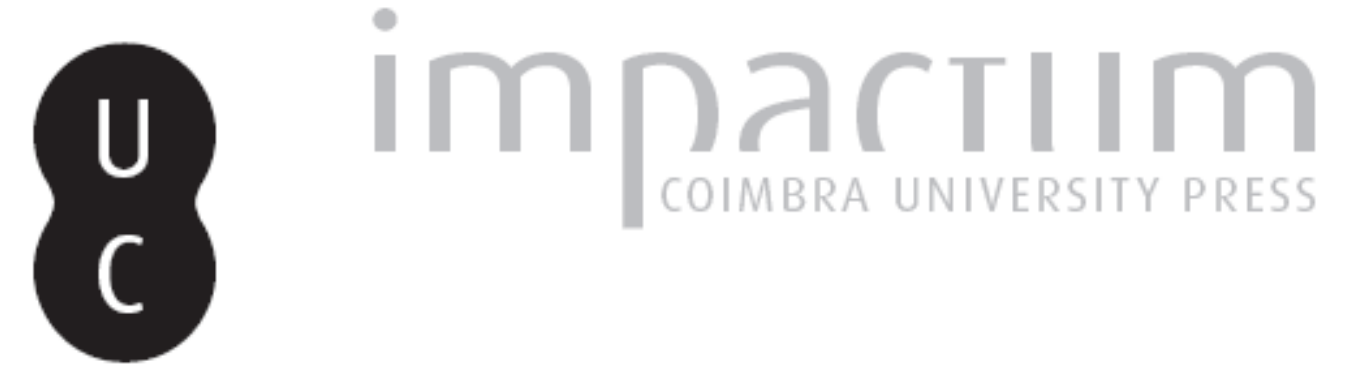

"The blacks of Indonesia": the articulation of papuan ethnic identity on social media Autor(es): $\quad$ Surya, Yuyun W.I

Publicado por: Imprensa da Universidade de Coimbra

URL persistente: URI:http://hdl.handle.net/10316.2/39632

DOI: $\quad$ DOI:http://dx.doi.org/10.14195/2183-5462_29_6

Accessed : $\quad$ 26-Apr-2023 16:29:13

A navegação consulta e descarregamento dos títulos inseridos nas Bibliotecas Digitais UC Digitalis, UC Pombalina e UC Impactum, pressupõem a aceitação plena e sem reservas dos Termos e Condições de Uso destas Bibliotecas Digitais, disponíveis em https://digitalis.uc.pt/pt-pt/termos.

Conforme exposto nos referidos Termos e Condições de Uso, o descarregamento de títulos de acesso restrito requer uma licença válida de autorização devendo o utilizador aceder ao(s) documento(s) a partir de um endereço de IP da instituição detentora da supramencionada licença.

Ao utilizador é apenas permitido o descarregamento para uso pessoal, pelo que o emprego do(s) título(s) descarregado(s) para outro fim, designadamente comercial, carece de autorização do respetivo autor ou editor da obra.

Na medida em que todas as obras da UC Digitalis se encontram protegidas pelo Código do Direito de Autor e Direitos Conexos e demais legislação aplicável, toda a cópia, parcial ou total, deste documento, nos casos em que é legalmente admitida, deverá conter ou fazer-se acompanhar por este aviso. 


\section{Media Jornalismo}

\section{MÉDIA E COLONIALISMO(S)}




\title{
"THE BLACKS OF INDONESIA": THE ARTICULATION OF PAPUAN ETHNIC IDENTITY ON SOCIAL MEDIA
}

\author{
YUYUN W.I SURYA ${ }^{1}$ \\ UNIVERSITAS AIRLANGGA SURABAYA/ FACULTY OF SOCIAL AND \\ POLITICAL SCIENCES /COMMUNICATION DEPARTMENT \\ SURABAYA, JAWA TIMUR \\ INDONESIA 60286 \\ YUYUNWSURYA@YAHOO.COM
}

\begin{abstract}
This study aims to explore how Indonesian ethnic minorities construct their identity online. It will focus on the way Papuans articulate their ethnic identity online particularly on Facebook. It looks for the way in which Papuans present and express themselves through posted and shared messages. The articulation of Papuan identity from the Papuans' view is significant due to the fact that Papuans were denied the freedom to express their ethnic identity. Multimodal discourse analysis is chosen as the method. This method offers a tool to collect and analyse data that is appropriate to study texts in social media. This study will provide analysis on the way Papuans articulate their "Papuanness", through the posted messages within the Orang Papua group. It reveals that through social media, Papuans are strengthening their identity by raising their distinctive ethnic consciousness. Papuans are emphasising their affiliation to Melanesian race to show their ethnic distinctiveness and to contrast with Indonesians, creating the notion of ethnic authenticity to redefine their ethnic identity, contesting the negative stereotype previously attached to them to empower themselves. Papuans' marginalisation, oppression and economic exploitation along with being recognised by their black skin and curly hair, have made Papuans "the Blacks of Indonesia". Papuan ethnic consciousness is facilitated by Facebook platform which allow them to choose and post messages to support their preferred online identity. Through social media, members of the Orang Papua group have shown attempts for power struggle by constructing identity according to their values and interests.
\end{abstract}

\section{KEYWORDS}

Ethnic identity, Authenticity, Strategic essentialism, Papuanness, Social media

1 Yuyun W.I. Surya is a lecturer at Communication Department, Universitas Airlangga Surabaya, Indonesia. Currently a PhD candidate at the University of Auckland, New Zealand. She got her master degree at Monash Unversity, Australia. Her research interests are online media, multiculturalism and identity. e-mail:yuyunwsurya@yahoo.com or ysur846@aucklanduni.ac.nz 


\section{INTRODUCTION}

The history of Indonesia witnessed ethnic-based movements aimed to separate from the unitary state. Magenda (1990 in Gayatri, 2010) noted that the primary cause of these ethnic-based movements was the dominant control of the central government followed by cultural hegemony and cultural uniformity that marginalised particular ethnic identities. Papuans were denied the freedom to express their ethnic identity and their cultural expression was viewed with suspicion and usually interpreted as a manifestation of Papuan nationalism (Bertrand, 2004: 151). The lack of democratic space in Papua resulted in rising ethnic tensions and separatist activities. In this regard, Papuans felt that they were being colonised. Bertrand argues that the Indonesian government ruled the province in a way that was reminiscent of colonialism (2004: 150). Papuans received few benefits from the economic development of their province after the discovery of copper and gold explored by PT Freeport-a US-based mining company. Few of them were hired at the mine and if they were, obtained only low-skilled jobs. The economic disadvantage along with unequal treatment has made Papuans demand to become a separate nation from Indonesia.

For Papuans, a major role in strengthening ethnic sentiment in Papua are ethnic distinctiveness, along with the dispute of the historical grievance, extensive use of coercion and violence by central government and the exploitation of natural resources that caused economic inequality. The Papuan identity became a form of opposition to Indonesians, who are known among Papuans as "amberi" (foreigners). They looked upon the West Papuans as primitive and uncivilised, an attitude still dominant among Indonesians today. Papuan nationalists believe that "depapuanisation" is what the Indonesian government has been trying to do since 1963. This attempt includes banning traditional Papuan apparel and hampering traditional governance, as well as restricting cultural practices and symbols (Trajano, 2010). Along with "depapuanisation" is the process of "indonesianisation" through the spreading of Javanese culture, of Islam (by building mosques in Christian-dominated Papuan viIlages), and of the history of Indonesian revolution.

In the 1970s and 1980s, the Indonesian government accelerated its transmigration program, under which tens of thousands of Javanese migrants were resettled in Papua. The current government has reintroduced this program. This has made indigenous Papuans into a minority in their own region. From the government's perspective, the "transfer of ethnic groups" is advantageous for migrants, who are able to access land, as well as for the indigenous people, who can benefit from "modernising influences" of Javanese culture (Aragon, 1994). By 2000, Indonesian settlers constituted $66 \%$ of the urban populations. This demographic transformation along with Indonesian dominance of the local economy and administration only reconfirmed local perceptions of Papuan exploitation.

In the political history of Indonesia, the internet had acted as "cyber-civic space" in which individuals and groups encourage collective activism online and translate it into movement offline (Lim, 2013: 639). The internet has become a space of resistance for Indonesians, particularly during the reformation struggle against the new order regime in late 1990s. With a remarkable growth in social media usage, with $90 \%$ of online activities devoted to browsing social network sites (Galih and Ngazis, 2012 in Lim, 2013) along with the restrictions on mainstream media, and the lack of 
control mechanism on social media contents, some might expect social media to be utilised greatly for political and social events. Previous studies (Lim, 2013; Nugroho and Syarif, 2012; Sen \& Hill, 2000), indeed, demonstrate that the internet, and social media in particular, has had some major in political roles in Indonesian society.

\section{Literature Review}

Social media like Facebook offers wider opportunities for identity to be explored. It gives "a moral encompassment within which we have a sense not only of who we are but also who we ought to be" (Miller, 2011: 180). Facebook provides users the ability to perform activities such as status updates, to express preferences and to connect with others. Zhao et. al (2008) noted that social media such as Facebook had provided an opportunity for users to claim their identity implicitly rather than explicitly "show rather than tell". In addition, Mehdizadeh (2010) stated that social media provides an ideal environment for the expression of the "hoped-for possible self" a realistic, socially desirable identity an individual would like to establish given the right circumstances. While the previous studies concentrate on the conception of identity, grounded only in user profiles and lack of analysis in the interactions users made in social media, my study will focus more on interactions users made through posted messages as well comments, "liking" and "sharing", as they will provide evidence of a more dynamic conception of constructing ethnic identity in social media. Studies by Zhang, et al (2010) and Frazier and Zhang (2014) underline the importance of the construction social identities that are embedded in social interaction in social media sites.

\subsection{Ethnic Identity in Online Media}

Identity is the central building block of social media (Kietzmann, et al, 2011). Social media activities are defined by the extent to which they focus on seven functional blocks: identity, conversation, sharing, presence, relationships, reputation and groups. Eisenlauer (2013: 18) states that "social network sites are application systems that offer users functionalities for identity management (i.e the representation of the own person in the form of profile)." Thus, the characteristics of social media may affect the way users construct their ethnic identity. It facilitates "organic content, distributed processing and interaction and converging media format" (Andreas in Lim, 2013: 638). Social media users may develop a narrative of identity that is different from other online forms.

This study chooses to use ethnic identity because this term focuses on Papuans as one of the ethnic minorities in Indonesia who experience marginalisation. Leung (2005: 12) argues that ethnic identity is a term of marginalisation since "everyone has an ethnicity yet it only seems to be applied to minorities, anyone who is 'ethnic' either does not quite belong, or belongs elsewhere or on the peripheries".

According to Phinney (2003), ethnic identity refers to how individuals interpret and understand their ethnicity (in Xu, 2014). Further, Nagel (1994) argued that ethnic identity is determined by the individual's perception of its meaning within a specific social context. Zhao, et al (2008) stated that identity construction is a process that involves both "identity announcement" made by the individual claiming the identity and "identity placement" made by others who endorse the claimed identity. One 
important aspect of these definitions is that ethnic identity can be best understood as both depending on individual interpretation and on the results of social construction. This perspective is useful since my study focuses on the construction of ethnic identity as the result of interactions. The dual aspect of the ethnic identity construction process is quite often neglected in approaches that stress the role of social representation of identity (Verkuyten, 2005). The identity construction process thus requires an individual who declares an identity and a society that endorses the asserted identity. This statement suggests that if a society does not endorse the chosen identity, a person may feel anxious and experience an anomie (a feeling of being alienated and unaccepted). As the issues concern both personal interpretation and social construction, this suggests the centrality of "personal self-recognition" (Calhoun, 1994: 20) as well as recognition by others, in ethnic identity.

\subsection{Hybridity, Authenticity and Strategic Essentialism in Ethnic Identity}

There are diverse ways in which ethnic groups or individuals negotiate and work at asserting their ethnic identities. Kellner (1995: 232) noted that "in modernity, identity becomes more mobile, multiple, personal, self-reflexive, and subject to change and innovation". This leads to Homi Bhabha's (1994) notion of mixture or hybridity in ethnic identity. Bhabha argues that hybridity arose out of the culturally internalised interactions between "colonisers" and "the colonised" (in Yazdiha, 2010: 31). Leung (2005, p.23) posits that ethnic identity can refer to identities in a dynamic states of hybridity. Verkuyten (2005: 151) noted "theories of hybridity emphasise the mixing and fusion of meanings and reject the notion of homogeneous, uniform identities. Increasingly the notions of heterogeneity and multiple identities are being advanced."

The term ethnic implies a sense of place and belonging and therefore links closely with a concept of a nation and its natives (Hall, 1992 in Leung, 2005: 24). It is being used by a community as the vehicle for claiming singular and homogenous ethnic group by formulating an identity that only emphasises a certain attribute of a community. In this regard, authenticity is privileged over the complexity of difference. Generally, construction of authenticity involves successful signification of what is accepted as "real" or "true" for individuals' identities.

The idea of authenticity gains its force from essentialism. Bucholtz (2003: 400) describes essentialism as the position from which the attributes and behaviours of socially defined groups can be determined and explained by reference to biological and/or cultural characteristics believed to be inherent to the group. Essentialism assumes that groups can be clearly delimited and group members are more or less alike. In this sense, it is extracting a core element of a group and emphasizing them with the aim of creating solidarity and strengthening their presence in society. Further, it can also be used for political mobilisation. Spivak (1988) coined the term "strategic essentialism" to explain a political tactic employed by a minority group acting on the basis of a shared identity in the public arena in the interests of unity during a struggle for equal rights. Dourish (2008) posits that strategic essentialism is the means by which subordinate or marginalized social groups may temporarily put aside local differences in order to forge a sense of collective identity through which they band together in political movements. As a result, strategic 
essentialism would at some point exclude certain voices and ignore differences. Thus, even though there are no fixed truths to be found about identity categories, strategic essentialism argues that we can act as if the identity was a stable entity for specific political and practical purposes.

\section{Methodology}

This study aims to explore, and critically analyse, the way Papuans construct their ethnic identity on a Facebook group called Orang Papua (People of Papua/Papuans). Facebook is selected because of its interactive, multimodal and user-centred nature. It facilitates the construction and representation of a variety of identities (Kahn and Kellner, 2004 in Khosravinik and Unger, 2016, p. 211). The ubiquity of Facebook, coupled with the ease with which a group can be formed, makes it a convenient form of political expression (Marichal, 2013). Orang Papua group is selected due to the largest number of members comparing to other similar social media groups. There are no available of avenues for Papuans to articulate their views and interests, and activists are not allowed to have peaceful rallies, books that discuss human rights violation and Indonesian military occupation in Papuan are banned (Trajano, 2010: 280). Moreover, the outlawing of public display of symbols of Papuan identity, along with the importance of ethnic identity that have given rise to Papuan political resistance and the absence of Indonesian government control of social media bring to the fore the issue of how Papuans are articulating themselves through social media.

In order to answer the questions of the construction of Papuans' ethnic identity on the Facebook group Orang Papua (People of Papua/Papuans), I will use a qualitative textual analysis approach. Multimodal discourse analysis is chosen as the method, which offers a tool to collect and analyse social media multimodal text that is information conveyed in various modes, which include visual, audio, and moving images (Eisenlauer, 2013: 309). KhosraviNik and Zia (2014) posit that social network sites have pushed multimodality analysis much more to the centre of discourse analysis. This research will select and analyse multimodal texts from posts and comments containing Papuan ethnic identity. Jager (2001) explains that a text or part of a text can address certain themes. Texts containing ethnic identity theme can be identified through their discourse fragments (in Wodak, 2002: 47) in the form of words, layout, colour and sound. The discourse fragments of ethnic identity texts refer to the components of ethnic identity, such as: self-identification/label, a feeling of belonging, and attitudes toward other groups (Phinney, 1992: 158-161).

\section{Analysis and Findings}

\subsection{The Orang Papua Group}

This group was created on 7 March 2010. As written in the group description, this group provides a place for Papuans, include Papuans who live outside Papua, to interact to one another and to discuss "Papuans' basic rights" along with developments in regencies and provinces in Papua. According to the group description, the importance to discuss the Papuans' basic rights and development are further explained within the context of the conflict in Papua. The never-ending Papua-Indonesia conflict 
has made Papuans' basic rights are violated and neglected. Furthermore, the civilians being shot (by Indonesian armed forces), and labelled as separatists, the impact of transmigration program for community in Papua, the natural resources' exploitation that give no benefits to Papuans and the failure of the development in Papua due to local government's corruption toward a grant provided through special autonomy program are descriptions of the omission of the Papuans' basic rights. Thus, instead of explicitly claim to support Papuan's political struggle for independence, this group demand a change (Perubahan) for Papuan's welfare. This demand has been written in capital letters in group description indicate the emphasis of the group's purpose.

Another emphasis is given in the last part of the group description. It is written that Papuan should become a warrior of thoughts and a thoughtful warrior (Pejuang Pemikir \& Pemikir Pejuang). The term Pejuang Pemikir \& Pemikir Pejuang implies that the fight against the unjust situation in Papua requires Papuans who have both intellectual capacity and ability to execute and take action. The use of the term warrior (pejuang) indicates the creator of the group's view of Papuans who need to fight against discrimination and repression. A warrior of thoughts and a thoughtful warrior can be achieved through the use of social media group where Papuans can exchange information to develop discourses aimed to deliver awareness of current situation in and of future for Papua. This motto can also be seen as an indication to the need of a different mode of resistance for Papuans since previously Papuans, particularly Free Papua Movement (OPM), were famous for their guerrilla form of resistance. Moreover, this motto has also brought the importance role of online media, especially social media in Papuan's political resistance.

As of February 2016, there are over 63 thousand members joined in this group. Its membership is through group admin approval, yet once an individual has joined the group, he/she can individually invite friends to join this group. This group was initially an open group. It became a closed group in 2015. Although there are no further explanations on the reason provided within the group, it can be assumed that it is due to the request of some members who observe that this group became a place to condemn Papuans who express their anger to Indonesian government by non-Papuans members or by Indonesian supporters.

The articulation of Papuan identity from the Papuans' view is significant due to the fact that Papuans were denied the freedom to express their ethnic identity. In this sense, the expression of Papuan identity (Papuanness) became the core of their political struggle to form a nation separate from Indonesia. Through Facebook, Papuans have the freedom to choose how they wish to present themselves and also how they express their political resistance. In this regard, the articulation of Papuan identity online plays a pivotal role in and is a part of their online activism.

The challenge to construct Papuan identity has taken place within the context of Indonesianisation for almost fifty years. As noted by Gietzelt (1989), Papuans "learned to be Indonesians" through the education system, the media, economic development and transmigration. These systematic programmes aimed to incorporate the Papuan population into the Indonesian nation-state. Online media became the only means for Papuans to articulate freely their identity since mainstream media, education and economic sectors are dominated by Indonesia and are still under the government's control. In social media, Papuans can post links, 
add comments, and likes as well as spreading and sharing messages to develop the narrative of their identity.

Through social media, Papuans are strengthening their identity by raising their distinctive ethnic consciousness. Papuans are emphasising their affiliation to Melanesian race to show their ethnic distinctiveness and to contrast with Indonesians, creating the notion of ethnic authenticity to redefine their ethnic identity, contesting the negative stereotype previously attached to them to empower themselves. The strengthening of Papuan identity is indeed very crucial for the rest of the Papuans to come together and be united in liberating their homeland. Papuan ethnic consciousness is facilitated by Facebook platform which allow them to choose and post visual images and messages to support their preferred online identity. This preferred online identity reflects Papuans' desire to form their Papuanness.

Even though there is a contestation of the notion of Papuanness, members of the Orang Papua group employed strategic essentialism as they tried to put aside differences for the sake of a political goal. The narrative to reject Indonesian domination in Papua and which has made Papuanness, does not encompass the wide range of differences which migration has produced such as mixed-race communities and a variety of religions, and does not accommodate different ethnic groups in Papua which have various cultures, languages and a slightly different physical appearance. The use of physical characteristics showing ethnic distinctiveness to articulate identity in social media, according to Miller (2011) is because "Facebook is a virtual place where you discover who you are by seeing a manifestation of yourself. Facebook has given an encompassment within which we have a sense of not only who we are but of who we ought to be" (Miller, 2011: 179-180).

Through Facebook, members of the Orang Papua group have shown attempts for power struggle by constructing identity according to their values and interests. According to Castells (2015: 5) power is exercised not only by means of coercion but also by the construction of meaning in people's minds. For society at large, the key source of the social production of meaning is the process of communication by which there is the process of sharing of meaning through the exchange of information. Within the context of social media, the process of constructing meaning is characterised by and is dependent on the messages and frames created, formatted and diffused in multimedia communication networks. Castells (2015: 6) suggests that the transformation of the communication environment directly affects the forms of meaning construction, and therefore the production of power relationships. Castells further argues that "people can only challenge domination by connecting with each other, by sharing outrage, by feeling togetherness, and by constructing alternative projects for themselves and for society at large" (2015: 257).

\subsection{Self identification/Label: Papuans' Melanesian Race}

Race refers to human groupings whose members possess common physical characteristics. From this viewpoint, the only properties that count are the immediately visible ones: skin colour, body, hair and facial configuration. These physiological characteristics were used to justify a dichotomy between the superiority and inferiority of a particular race. Race is a problematic term because it utilises symbolic markers of the body to make a socially constructed difference into a supposedly 
natural one. The concept of race emerges in a particular social and historical context. Leung (2005: 25) argues that the use of race as a category for describing difference was prevalent in the imperialism context along with the ideas of biological determinism. The invention of Oriental/the East as opposed to European/the West, in which the West was defined as everything that the East was not, is parallel to the dichotomy of race. Race as a social construction and not a universal or essential category of biology becomes the basic argument for the idea of race formation or racialisation. According to Barker (2004) racialization is "the process by which a group is 'turned into' a race through racial classifications constituted by power".

Van der Kroef (1975) stresses that "by Papuan ethnicity is meant a sense of cultural distinctiveness, suffused by racial self-perceptions and sharpened by the presence of Indonesian ethnic groups (in Gietzelt, 1989: 209). While the dichotomy of race has been widely criticised for being scientifically invalid, it persists in the discourse of difference. Thus, this study acknowledges that any notion of race premised on biological or physiological characteristics is fundamentally flawed, but uses the term to refer to strategies for representing difference. Leung (2005: 25) states that race remains in widespread use to delineate difference. The use of the term is particularly related to the fact that Papuan ethnic distinctiveness is determined by racial affiliation to Melanesia as an attempt to differentiate themselves from Indonesians.

Members of the Orang Papua group frequently label themselves as having "black skin and curly hair". As shown in their posted-images, Papuans have made their distinct skin and hair visually prominent. This indicates how black skin and curly hair is attributed to Papuans and becomes an "idealised Papuans". The emphasis on physical appearances is also displayed through the use of images depicting physical characteristics along with explicit verbal messages, such as "I am Papuan. I have black skin and curly hair". It functions as a declaration of affiliation to Melanesian as well as a differentiation from the majority of Indonesians who belongs to the Malay race. Furthermore, the visual image depicting distinct physical characteristics of Papuans along with the explicit verbal message are not only used as evidence of their identity, but also as an assertion of their capability to articulate their distinct identity confidently. This self-confidence is important due to historical relations with Indonesians whose patronising attitudes toward Papuans undermined their identity and dignity (Trajano, 2010: 18).

The affiliation to the Melanesian race becomes politicised when discussed in relations to Papuan identity. Since Papuans took black skin and curly hair as the symbolic markers of their identity, the concept of race is also used to indicate political unity rather than only to describe distinct physical characteristics. Gietzelt (1989: 210) argued that this identification with blacks has political motivations in that "it is used to arouse sympathy for, and indeed empathy with, the Papuan cause among black minorities elsewhere, who may be sensitive to charges of lingering colonialism". Thus, the black skin and curly hair is not only a label for Papuan ethnic identity but also a symbol of resistance. Papuans' marginalisation, oppression and economic exploitation along with being recognised by their black skin and curIy hair, have made Papuans "the Blacks of Indonesia". Silk (1990) and Ross (1996) argue that black refers to those who have been subject to slavery, segregation, discrimination and economic exploitation (in Leung, 2005: 26). Within the historical 
context of western countries, black is a symbol of oppression and resistance and is intended as a sign of solidarity for those who have been discriminated against for their non-whiteness.

Connectivity is one of the prominent platforms of social media. Van Dijck (2013: 202) posits key terms such as 'friending', 'liking', 'sharing' and 'following' are signifying activities in social media such as Facebook. Further he states that 'liking' is a gesture generating information about people's desires and preference and 'following' indicates people's interests and allows for the detection of trends. In this study, posted messages contain black skin and curly hair received likes as well as comments from other members of the group. While the number of like is surprisingly insignificant (most of the posted messages received less than 100 likes) compare to the total members of the group (over 56 thousand members by December 2015), it is still an indication and a form of wordless support and the easiest detection of an approval of the information conveyed. According to Facebook the like button, which was added to in February 2009, is a way to give positive feedback or to connect with things users care about on Facebook. Facebook like can also be interpreted as an easy form of self-presentation attach to meaningful engagement (Mehdizadeh, 2010). Furthermore, previous research by Enjolras, et al (2012) has showed that liking practices on Facebook are part of a new and emerging type of online civic engagement and social mobilisation (in Brandtzaeg and Haugstveit, 2013: 2).

A more explicit engagement on Facebook is indicated by comment since users can express and articulate their opinion verbally as well as visually. Unlike the like function, comment is an obvious response to the posted messages which is more conversational. Moreover, comment function offers users to express both agreement and disagreement and thus to create wider opportunity for debate and discussion. In this study, posted messages contain black skin and curly hair received supportive comments such as "awesome", I am Papuan, too" or "Papuan Melanesian is great." In this sense comment function lets members of the group develop the narrative of Papuan identity. In fact, Facebook's mechanism supports the narrative users intend to develop since it allows users to remove unwanted comments.

However, there has been rejection of the notion of black skinned and curly haired Papuans. Nakamura and Chow-White (2012) argues people can cultivate and use online media to construct and promote both dominant and resistant ideas. This uniformly defined Papuan identity is contested by the mixed-race members of the Orang Papua group. The mixed-race/hybrid individuals have the physical characteristic that their skin and hair is sometimes neither black nor curly. The contestation in defining who is and what is Papuan in this group indicates the struggle over the meaning of Papuanness. Furthermore, it is also an indication that this group offers a discursive site of contestation regarding Papuan identity. Thus this proves the fact that there is no fixed and stable meaning of identity. This rejection is expressed through posted visual and verbal messages as well as through thread of comments.

Viartasiwi (2013: 863) argued that the group outside the mainstream category of Papuan is "never enough to be Papuan". The mixed-race communities exist as a result of migrants coming to Papua. Viartasiwi (2013) states that Papua in the $21^{\text {st }}$ century is also the home of mixed-race communities and individuals, mainly due to massive transmigration since 1970s from more populous islands in Indonesia, es- 
pecially from Java to Papua. Some members of the group have expressed their differences visually and verbally in their posts. Members of the group who are mixed-race Papuans tend to provide argumentation to show that they are part of Papuan, and that they want to be Papuan, and that they should be recognised as Papuan. Thus, they put more effort into being acknowledged as Papuan. They are calling for greater expansion of what it means to be Papuans beyond the dominant discourse of the black skin and curly hair category.

The non black-skinned and curly-haired Papuans also expressed themselves in the group. Some posters are needed to explain that they are Papuans although they do not have such typical physical characteristics. A young man explains that he considers himself Papuan although he has light skin as the result of a mixed-race marriage. A Papuan woman posted her picture with her darker-skinned friend aimed at showing that she, too, is Papuan. She wrote that "the Papuan is based on what is inside and cannot be defined by their skin. Papuan is (defined) by heart and not by skin". These posted messages received likes and comments from members of the group although lesser compare to the black skin and curly hair posted messages. Unlike comments on the black skin and curly hair messages, which are mostly expressing supports, there are less supportive and even discouraging comments on the mixed-race/hybrid Papuans messages. Assertions of discouragement for the mixed-race Papuan show in the comment posted by one of the members who wrote "for those who are only born in Papua, prove your love for Papua". The use of the words "only born in Papua" refers to the individuals who are not belongs to Melanesian race. This statement also reflects that there is a hierarchy of the Papuans, that the mixed-race Papuans are lower than Melanesian race Papuans and thus must demonstrate their intention to be Papuans. The mixed-race/hybrid Papuans posted messages indicate an attempt to contest the notion of Papuanness. However, the comments received shows that there is a rejection to this attempt. In this sense, the hybridity discourse is in the minority against the essentialist discourse.

The domination of essentialist discourse in the notion of Papuan identity proves the fact that members of Orang Papua group employ strategic essentialism in the articulating their identity. They act as if their identity is a stable identity by ignoring mixed-race Papuans and at the same time put the black skin and curly hair as the only marker for their identity.

\subsection{A feeling of belonging: Authenticity in Papuan identity}

The issue of black skin and curly hair as an idealised Papuan as well as the existence of a group outside this category, have brought the discourse of authenticity in Papuan identity. Papuans use the term OAP/Orang Asli Papua ("true Papuan or authentic Papuan") to refer to the notion of Papuans' authenticity. Bucholtz (2003: 401) argues that the concern with authenticity emerged from the socio-political conditions. I argue that the notion of the authentic Papuan aims to frame Papuan identity based on racial/ethnic heritage and to contrast the notion of amberi("foreigner" in Papuan language), a term that refers to Indonesians. The notion of the authentic Papuan is constructed within the discourse of physical appearance, nativity, and indigeneity shaped by Papuan-Indonesian's historical relations. 
Discourse over the definition of authentic Papuan or truly Papuan (Orang Asli Papua) is lively in Papua (Viartasiwi, 2013: 869). According to the Special Autonomy Law of Papua, the power to grant Papuan legitimacy is in the hands of the Papuan Council (MRP/Majelis Rakyat Papua). The definition of Papuan, according to this body, is one who has Melanesian descent and mixed-race communities are excluded. This definition can be interpreted as rejection of the existence of the non-Papuan born Papuan. The definition can also be read as an attempt to develop Papuans as more distinct from Indonesians and thus become a foundation to justify the struggle towards an independent nation. The MRP's definition provides a general and simplistic notion of who and what is considered as Orang Asli Papua since it only includes Papuans of Melanesian descent. The existence of the MRPS authority to define Orang Asli Papua indicates that essentialised identity is not only being internally formulated, but being imposed upon communities as well.

While there are no further explanations of the definition provided by MRP, this conservative claim of the authentic Papuan has opened up debates and contestation of the meaning of Orang Asli Papua among Papuans. Even though it is argued that the effort to impose a definition of authentic Papuans is helping and empowering Papuans to take on broader roles in the community's development, the benefit of imposing the MRPs definition of indigenous Papuans is still debatable. Some observers argue that the issue of Orang Asli Papua is an indication of the recognition of Papuans' rights given by the Indonesian government. Others contend that it is only a strategy of diversion from the Papuan political struggle to demand independence. The notion of Orang Asli Papua tends to be the political rhetoric of Indonesian government to counter negative images due to a long history of human rights violation and a military approach in Papua and to serve the interests of elite Papuans instead of a bottom-up discourse from grass roots Papuans. I contend that through social media, Papuans are contesting claims about the authentic Papuan. Members of the Orang Papua group came up with a narrative of who is considered as the authentic Papuans or Orang Asli Papua. Within this narrative, the notion of Anak Adat ("the son of the custom/tribe") and Orang Asli Papua is created and reproduced by members of the group as part of the group's identity even though there seem to be different interpretation of the definition of Orang Asli Papua among members of the group. This is due to the fact that Papuans tend to be essentialist in defining their identity. The more Papuans employ strategic essentialism to articulate their identity, the more they will question the authentic Papuan identity.

The social media's designated interfaces enable users to share information and connect with others purposefully. Brandtzaeg \& Haugstveit (2013: 5) argues that "Facebook liking behaviour appears to have become a vehicle for those who wish to inform others of what they perceive as desirable activities and to call forth a preferred presentation of the self. This type of action is possible because social media enables a large number of ordinary people to become linked to and recognised by a large number of other people". With the Facebook's ideology of sharing (van Dijck, 2013) especially the like and comment functions, Facebook have involved in the process of the Papuan identity paradox, where authenticity is called into question as members of the group employ strategic essentialism. 
Social media allows users to create a single axis of identity-that is emphasising one aspect in representing the self. It allows users to create profile contains both visual and verbal messages. When members of Orang Papua group post messages along with visual images of their selected identity emphasised on physical characters, on their wall and receive likes, this response may put pressure on other members of the group, particularly when the received likes are significant in quantities. They tend to identify that axis as their defining feature. This selected identity thus functions as not just describing but also dictating the identity that the members of the group should have. It is somewhat imposing the vision of Papuan identity onto all members of the group. On the other hand, social media like Facebook allows members of this group who are excluded from the definition of Orang Asli Papua to appear with their contested arguments through comments, since Facebook does not provide the not-like button. The unavailability of not-like button to show the instant disapproval of specific idea or item has given users chances to express further disagreement through comment button. By commenting users may develop connections with others and involve in more lively debates. In this sense, Facebook offers opportunity for members of Orang Papua group to construct Papuan identity and at the same time to challenge the notion of Orang Asli Papua.

From this point, it can be said that the notion of authentic Papuan identity refers to indigenous Papuans who do not change any of the distinct physical characters which they have, namely, their black skin and curly hair. Indigeneity is often defined either in criterial terms such as being the first inhabitants of a territory, or having a particular relationship with the land, or in relational terms such as the power dynamics between colonisers and indigenous communities, or between indigenous groups and the state. Thus, it emphasises the relationships of domination and exploitation imposed on indigenous communities by colonial powers. Furthermore, Timperley (2014: 19) suggests that, in defining indigeneity, we need to reconsider more recognition of the unique experience, history and culture of indigenous peoples. The notion of indigeneity for Papuans is shaped by the Indonesian historical domination over them, resulting in the consciousness of their ethnic distinctiveness.

The notion of the authentic Papuan, according to members of the group, is also determined by nativity. There is a posted-message shows a portrait of mama (a Papuan woman) Yosepha Alomang. She was awarded the Yap Thiam Hien prize in 1999 (the Indonesian version of Nobel prize) for her activity in conflict resolution and human rights in Papua. The posted message underlines Yosepha Alomang's statement during the rally when there was an official visit of foreign ministers from MSG (Melanesian Spearhead Group) to Papua in January 2014. Yosepha claimed that the reason why she joined the rally was that "I was just protecting Papuans who are born from a woman like me". The emphasis given by the poster to Yosepha's statement indicates the importance of avoiding mixed-race marriage especially for Papuan men since the authenticity of Papuans is determined by maternal lineage. In contrast, maternal lineage is not considered as one of the determinants in defining Orang Asli Papua according to the Raperdassus (RancanganPeraturan Daerah Khusus/ the draft of the special local regulation) regarding the mechanism produced by the MRP for deciding the head of province in Papua's election. The draft considers paternal lineage as one of the determinants along with Papuans whose parents are both of 
Melanesian descent as the main determinant for Orang Asli Papua. According to Yossias Saroy, the deputy head of Papua's regional regulatory body, Papuans, who have only Melanesian race from maternal lineage cannot be considered as Orang Asli Papua.(www.cahayapapua.com, 4 May 2015).

\section{Attitudes toward other groups: The Stereotypes of Papuan}

The historical contestation between Papuan and Indonesian identity has made Papuans place their identity distinct and in opposition to Indonesian. This binary opposition creates boundaries and leads to prejudice and discrimination, as one of the two opposites assumes on a role to be dominant over the other. Bodenhausen and Richeson (2010) argue that stereotypes, prejudice and discrimination is an interlocking phenomena. Bodenhausen and Richeson (2010: 346) states that, "one view holds that stereotypes give rise to prejudice (people develop antipathy toward a group based on characteristics the group is assumed to possess) and in turn prejudice gives rise to discrimination (people treat group members disadvantageously because of the antipathy or disdain they feel toward the group)." Further, Verkuyten (2005) posits that attempt to define identity by ethnic minority group is a response to status and power differences and the predicaments resulting from negative stereotypes and discrimination. Whilst Indonesians used to treat Papuans as inferior and uncivilised, I argue that members of the Orang Papua group have taken to social media to articulate their identity which presents argumentation that the previous stereotype was wrong as well as to reject the submissive role. Members of the Orang Papua group have utilised the primitive stereotype as a mode of resistance. The use of the notion of primitive Papuans is aimed to perpetuate the view that they have been colonised by Indonesian government. Moreover, the visual image depicting the primitive Papuan is used to support strategic essentialism in defining Papuan identity.

The negative stereotype attached to Papuans is shaped by the unequal relations between Indonesians and Papuans. The Indonesian government ruled the region in a way that was reminiscent of colonialism (Bertrand, 2004: 150). Hechter (1975) coins the notion of internal colonialism. He describes the concept of internal colonialism as the process by which the core (Indonesian government) dominates the periphery (Papua) politically and exploits it economically. Resources and power are distributed unequally between the dominant ethnic group (the core) and the ethnic minorities. Substantial economic inequalities along with unjust and illegitimate situations are conditions for the emergence of ethnic minorities' solidarity and nationalism. Papuans have experienced marginalisation, oppression and economic exploitation (Trajano, 2010: 18). The Indonesian government has sought to civilise Papuans to make them think, act and look like Indonesians by banning traditional Papuan apparel, hampering traditional governance, as well as restricting cultural practices and symbols. Within this context, members of the Orang Papua group express the feeling of being marginalised, oppressed and discriminated.

The discrimination experienced by Papuans is articulated in the posted-message through the sentences "humans usually see others through eyes and not through heart, although you are wearing clothes, in God's eyes you are wearing nothing. Your skin is light, yet your heart is even darker than our skin". These statements imply the author of the post's view of the unequal relations between Papuans and 
Indonesians. The image depicting the Papuan with traditional apparel perpetuates the idea that the inequality is due to Papuans' distinct physical appearances. The concern with inequality is related to status and power differences that lead to a dichotomy model. There is a clear dichotomy between the primitive and the civilised. In the case of Papuans, the attempt to civilise them has brought about the notion of the primitive Papuans. Instead of using verbal message that is explicitly mention the word "primitive", this posted message is using visual image depicting prominent physical characters to represent "the primitive". In this sense, it indicates that instead of resisting the primitive stereotype, members of Orang Papua group adopt this stereotype to support strategic essentialism in defining their identity. Furthermore, the notion of primitive Papuans is being utilised to perpetuate the view of Indonesian government as coloniser.

Due to the negative stereotypes that are still attached to Papuans up till now, members of Orang Papua group make equality the salient issue. Van der Kroef (1976) argued that the issue of racial distinctiveness is not only a matter of the fact that "significant racial differences actually exist, but whether they are perceived as existing"(in Gietzelt, 1998: 210). For Papuans, racial difference is perceived as status and power difference. Papuans have always viewed themselves as powerless. Members of the group showed an attempt to reject Papuan's submissive role as well as negative stereotypes by developing the narrative of successful Papuans. It implies that Papuans have similar capability with Indonesians. Pictures of young male and female Papuans who successfully became pilots along with the message, emphasise that Papuans can and do have the ability to be anything they want to be. One of the photos depicts Papuan mothers who are very proud of their sons joining the Indonesian armed forces, as well as the pictures of Lenis Koyoga and Yohana Yambise who have been appointed as Indonesian presidential special staff member and minister of woman empowerment. While previously Papuans were depicted in native clothes and in native settings such as rural areas (Nakamura, 2002: 19), there are pictures depicting Papuans without their native apparels indicate that Papuans are civilised and are able to compete with others. These posted messages are also an attempt to negate previous Papuans' incompetent stereotype.

\section{ConcLusion}

Hall (1990) argues that identities are "subject to the continuous 'play' of history, culture and power. They are the name we give to the different ways we are positioned by, and position ourselves within, the narrative of the past." This paper suggests that the notion of Papuanness is defined as simply being in contrast to Indonesians. It is due to Papuans' "colonial experience" (Hall, 1990 in Ashcroft, et al, 2006: 435) since the region was integrated into Indonesia and Indonesians were regarded as colonising Papuans. The "black skin and curly hair" which has been selected as the symbolic marker of Papuan identity played as the idealised as well as "imaginary" Papuan. Zizek (1989 in Mishra, 1996: 448) defines the imaginary as the state of "identification with the image in which we appear likeable to ourselves, with the image representing what we would like to be."

It is evident in this study that the more Papuans insist on employing identity essentialism the more they will question the authentic Papuan identity. The Papuan 
identity essentialism organises itself for the purpose of challenging orders of domination and oppression, yet in so doing represses and erases the complexities of its own constituency, committing a similar form of violent dominance.

Authenticity is being discursively contested on Orang Papua group. There were arguments take place between ones who clearly asserted the notion of authenticity is determined by indigeneity and ones who believe that it has been created for political interests. The narrative of successful Papuans is not only an attempt to negate negative stereotypes attached to Papuans but also play as the projection of civilised Papuan society at large that has the potential to be an independent nation. As argued by Castells (2015: 251) people can only challenge domination by connecting with each other, by sharing outrage, by feeling togetherness, and by constructing alternative projects for themselves and for the society at large. Therefore, the articulation of Papuan identity in the Orang Papua group becomes part of the Papuan political movement's narrative to reject Indonesian domination in Papua. Members of the Orang Papua group have made and created this group as a symbolic public space, that is, a space for sovereign assemblies to meet and to recover their rights of representation. In this sense, this group ultimately becomes a political space.

\section{Bibliographic References}

Aragon, L. (1994). Multiculturalism: Some Lessons from Indonesia Accessed 4 September 2014 from https://www.culturalsurvival.org/publications/cultural-survival-quarterly/indonesia/multiculturalism-some-lessons-indonesia

Bertrand, J. (2004) Nationalism and Ethnic Conflict in Indonesia, Cambridge: Cambridge University Press.

Bodenhausen, G. \& Richeson, J. (2010) "Prejudice, Stereotyping, and Discrimination" in Baumeister, R. \& Finkel, E. (ed) Advanced Social Psychology: the State of the Science, London: Oxford University Press Accessed 20 November 2015 from http://faculty.wcas. northwestern.edu/bodenhausen/BRAdvanced.pdf

Bondi, L. (1993)."Locating Political Identity" in Keith. M. \& Pile, S (eds) (1993). Place and Politics of Identity, London: Routledge

Brandtzaeg, P. \&Haugstveit, I (2013) Facebook Likes: A Study of Liking Practices for Humanitarian Causes Accessed 23 December 205 from https://www.researchgate.net/profile/ Petter_Brandtzaeg/publication/264816197_Facebook_likes_a_study_of_liking_practices_for_humanitarian_causes/links/00b7d53b25e297962c000000.pdf

Bucholtz, M (2003) "Sociolingustic Nostalgia and the Authentication of Identity" in Journal of Sociolinguistics Volume 7, Issue 3 August 2003 Accessed 15 September 2015 from http://onlinelibrary.wiley.com/doi/10.1111/1467-9481.00232/epdf

Budiardjo, C. \& Liong, L. (1988). West Papua: The Obliteration of a People (3 $3^{d}$ edition), Surrey, UK: Tapol.

Calhoun, C. (ed) (1994). Social Theory and the Politics of Identity, Cambridge: Blackwell Publishers.

Castells, M. (2004) The Power of Identity, Carlton-Victoria, Australia: Blackwell Publishing. Chauvel, R. (2005). Constructing Papuan Nationalism: History, Ethnicity, and Adaptation, Washington: East-West Center. 
Ford, R.T. (2005). Political Identity as Identity Politics Accessed 22 December 2015 from http://legalleft.org/wp-content/uploads/2015/09/1UNB053-Ford.pdf

Frazier, R. \& Zhang, L (2014) "Ethnic identity and racial contestation in cyberspace: Deconstructing the Chineseness of Lou Jing" in China Information vol. 28 (2), 2014 Accessed 16 November 2016 from http://cin.sagepub.com/content/early/2014/05/18/0920203X14532224

Gayatri, I. (2010). "Nationalism, Democratisation and Primordial Sentiment in Indonesia: Problems of Ethnicity versus Indonesian-ness (the cases of Aceh, Riau, Papua and Bali)" in Journal of Indonesian Social Sciences and Humanities Vol. 3, 2010 Accessed 8 January 2015 from http://www.kitlv-journals.nl/index.php/jissh/index

Gietzelt, D. (1989). "The Indonesianization of West Papua" in Oceania, Vol. 59, No. 3 (Mar 1989) Accessed 2 July 2015 from http://www.jstor.org/stable/40331090

Hall, S. (1990) "Cultural Identity and Diaspora" in Ashcroft, B. et al (ed) (2006) The Post-CoIonial Studies Reader, London: Routledge.

Hands, J. (2011).@for activism: Dissent, Resistance and Rebellion in a Digital Culture, New York: Pluto.

Harlow, S. (2011). "Social media and social movements: Facebook and an online GuatemaIan justice movement that moved offline" in New Media and Society vol 14 (2), 2011 Accessed 31 March 2014 from http://nms. sagepub.com/content/14/2/225.full.pdf+html

KhosraviNik, M. \& Unger, J.W. (2016) “Critical Discourse Studies and Social Media: Power, Resistance and Critique in Changing Media Ecologies" in Wodak, R. \& Meyer, M. (ed) Methods of Critical Discourse Studies 3rd edtition, London: Sage Publications Ltd.

KhosraviNik, M. \& Zia, M. (2014) "Persian Nationalism, Identity and Anti-Arab Sentiments in Iranian Facebook Discourses: Critical Discourse Analysis and Social Media Communication" Journal of Language and Politics 13:4 (2014) Accessed 30 June 2016 from http:// www.jbe-platform.com/content/journals/10.1075/jp.13.4.08kho (

Kietzmann, J.H. et. al (2011). "Social Media? Get Serious! Understanding the Functional Building Blocks of Social Media" in Business Horizon (2011) 54: 241-251 Accessed 20 April 2015 from http://www.sciencedirect.com/science/article/pii/S0007681311000061

Kingsbury, D. (2003)." Diversity in Unity" in Kingsbury, D \&Aveling, H. (ed) (2003). Autonomy and Disintegration in Indonesia, London: Routledge Curzon.

Leung, L. (2005). Virtual Ethnicity: Race, Resistance and the World Wide Web, England: Ashgate.

Lim, M. (2005).@rchipelago online: The Internet and Political Activism in Indonesia, Enschede: University of Twente Accessed 20 February 2015 from http://doc.utwente.nl/50787/1/ Lim_thesis.pdf

Lim, M. (2013)."Many Clicks but Little Sticks: Social Media Activism in Indonesia" in Journal of Contemporary Asia Vol.43 no 4 Accessed 3 January 2015 from http://www.tandfonline.com/doi/pdf/10.1080/00472336.2013.769386

Marichal, J. (2013) "Political Facebook groups; Micro-activism and the digital front stage" First Monday, volume 18, number 12-2 December 2013. Accessed 30 June 2016 from http://firstmonday.org/ojs/index.php/fm/rt/printerFriendly/4653/3800

Mehdizadeh, S. (2010) "Self-Presentation 2.0: Narcissism and Self-Esteem on Facebook" in Cyberpsychology, Behavior and Social Networking Volume 13, Number 4, 2010 Acces- 
sed 3 January 2015 from http://online.liebertpub.com/doi/pdf/10.1089/cyber.2009.0257 (retrieved Miller, D. (2011). Tales from Facebook, Cambridge: Polity Press.

Mishra, V. (1996) "The Diasporic Imaginary Theorizing the Indian diaspora" in Ashcroft, B. et al (ed) (2006) The Post-Colonial Studies Reader, London: Routledge.

Nagel, J. (1994). "Constructing Ethnicity: Creating and Recreating Ethnic Identity and Culture" Social Problems Vol. 41, No. 1, Special Issue on Immigration, Race, and Ethnicity in America (Feb., 1994) Accessed 17 November 2014 from http://www.jstor.org/ stable/3096847?seq=2

Nakamura, L. (2002). Cybertypes: Race, Ethnicity, and Identity on the Internet, New York: Routledge.

Nakamura, L. \& Chow-White, P. (eds) (2012) Race after the Internet, New York: Routledge. Nishime, L. (2014) Asian American Experience Undercover Asian: Multiracial Asian Americans in Visual Culture, Urbana, Illinois: University of Illinois Press.

Phinney, J. (1992) "The Multigroup Ethnic Identity Measure A New Scale for Use with Diverse Groups" in Journal of Adolescent Research Vol. 7, No.2 April 1992. Accessed 30 June 2016 from http://jar.sagepub.com/content/7/2/156.full.pdf+html

Rumbiak, J. (2011)."West Papuan Independence Policies: Tension in the Transition" in King, P., Elsmlie, J., Webb-Gannon, C. (eds) (2011). Comprehending West Papua in http:// sydney.edu.au/arts/peace_conflict/practice/Comprehending\%20West\%20Papua.pdf (retrieved 1 October 2014).

Saunders, R. (2011). Ethnopolitics in Cyberspace: The Internet, Minority Nationalism, and the Web Identity,Maryland: Lexington Books.

Timpereley, C (2014) Constellations of Indigeneity: The Power of Definition Accessed 18 November 2015 from http://politics.virginia.edu/sites/politics.virginia.edu/files/Timperley_PTColloquium.pdf

Trajano, J (2010)."Ethnic Nationalism and Separatism in West Papua, Indonesia" in Journal of Peace, Conflict and Development /ssue 16 November 2010 in http://www.brad.ac.uk/ssis/ peace-conflict-and-development/issue-16/etthnicpapua.pdf (retrieved 8 January 2015).

Van Dijck, J. (2013) "You have one identity: performing the self on Facebook and Linkedln in Media, Culture and Society, 35 (2) Accessed 21 December 2015 from http://mcs.sagepub.com.ezproxy.auckland.ac.nz/content/35/2/199.full.pdf+html

Van Dijck, J. (2013)The Culture of Connectivity: A Critical History of Social Media Accessed 28 December 2015 from http://www.oxfordscholarship.com.ezproxy.auckland.ac.nz/ view/10.1093/acprof:oso/9780199970773.001.0001/acprof-9780199970773-chapter-3

Vegh, S. (2003). "Classifying Forms of Online Activism: The Case of Cyberprotests against the World Bank" in McCaughey, M. \& Ayers, M.D. (eds) (2003). Cyberactivism: Online Activism in Theory and Practice, New York: Routledge.

Verkuyten, M. (2005). The Social Psychology of Ethnic Identity, New York: Psychology Press. Viartasiwi, N. (2013). "Holding on a thin rope: Muslim Papuan communities as the agent of peace in Papua conflict" in Procedia Environmental Sciences 17 (2013) Accessed 7 July 2015 from http://www.sciencedirect.com/science/article/pii/S1878029613001060 (

Wardhani, BLS (2012) Papua on the Net: PerjuanganPemisahan Diri Papua Accessed 1 July 2014 from www.academia.edu/971617/Papua_On_the_Net 
Wodak, R. et al. (1999). The Discursive Construction of National Identity.Edinburgh: Edinburgh University Press.

Xu, Y, et al. (2014) "Ethnic identity and self-esteem among Asian and European Americans: When a minority is the majority and the majority is a minority" in European Journal of Social Psychology Accessed 2 September 2014 from www.wileyonlinelibrary.com

Yazdiha, H. (2010) "Conceptualizing Hybridity: Deconstructing Boundaries through the Hybrid" in Formations Vol.1 No.1 2010 Accessed 6 March 2015 from https://thefourthspace. wordpress.com/2013/02/08/notion-of-cultural-hybridity/

Zhang, S, et al (2010) "Social Identity in Facebook Community Life" in International Journal of Virtual Communities and Social Networking 2 (4), October-December 2010 Accessed 17 February 2016 from https://writingin.community.uaf.edu/files/2014/09/social-id-facebook.pdf

Zhao, S., et al (2008). "Identity Construction on Facebook: Digital Empowerment in Anchored Relationships" in Computers in Human Behavior 24 (2008) Accessed 2 December 2014 from http://www.elsevier.com/locate/comphumbeh 